\title{
Research on the Cultivation Dimension of Applied Talents in Engineering in Harbin based on "China- Made 2025"
}

\author{
LIN Zehong, ZHOU Xueyan, LUO Qiubin \\ Key Laboratory of Underground Engineering Technology \\ Harbin University \\ Harbin, China \\ dloinng@163.com
}

\begin{abstract}
China-made 2025" chooses the top 10 industries on behalf of China's strength of high-end equipment manufacturing industry. Based on the current situation of the training of engineering talents in Harbin colleges and universities, this paper mainly analyzes the current situation of talent cultivation, the present situation of personnel training and the dimensions of personnel training. Finally, give the prospect of Harbin's local economic development.
\end{abstract}

Keywords-China-made 2025; Talent Training Dimension; Engineering application talents

\section{INTRODUCTION}

"China-made 2025" is the Chinese version of "Industrial 4.0", which is a major deployment to strengthen China's manufacturing industry, enhance the international competitiveness of manufacturing, to ensure national strategic security. Harbin, as an important city in the northeast, was the cradle of the new China industry. In August 2015, the municipal government convened the "China-made 2025" mobilization meeting to launch the "China-made 2025" work promotion plan. According to the plan, the enterprise technological transformation, advanced equipment manufacturing and intelligent manufacturing and other major projects will be given priority support. At the same time, promote the transformation and development of industrial economy, and strive to focus on key enterprises, key industries take the lead in intelligent manufacturing, driven by regional manufacturing intelligent development made new breakthroughs.

\section{TyPES OF TALENTS TRAINING IN COLLEGES AND UNIVERSITIES}

The talents training in colleges and universities are mainly divided into two types: research and application. The talent demand of enterprises is mainly R\&D talents, transformation talents, production and management talents, among which R\&D personnel are mainly cultivated by research-oriented colleges, which belongs to elite education. Transformation talents are mainly cultivated by the teaching-oriented colleges and universities, which belongs to mass education. Production and management talents are mainly cultivated by vocational colleges. Fig. 1 shows the social talent pyramid structure, three types of talent and business needs one by one, and then meet the needs of social talent.

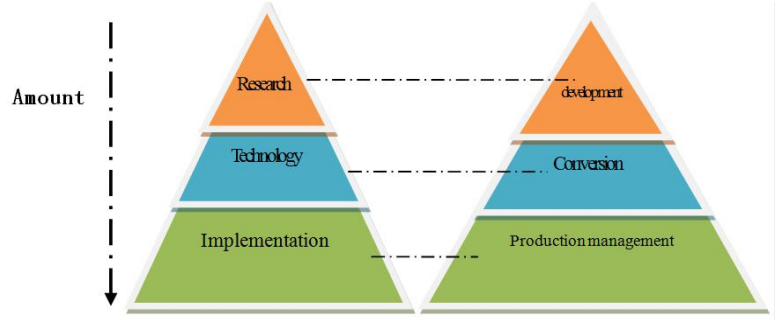

Fig. 1. Corporate talent structure chart

According to the analysis, the talent development is the fundamental to achieve the above objectives. The "high-quality application of technical talents" in the three kinds of talent has the role of under the "science and technology - technology achievement (products)" three links, is the transformation of science and technology into the nerve center, is to achieve "China made 2025"the backbone, with a pivotal importance.

\section{CURRENT SITUATION OF PERSONNEL TRAINING IN COLLEGES AND UNIVERSITIES}

It is very important to analysis the number, specialty distribution and enrollment scale of the "high-quality applied technology talents" cultivate in Harbin. At the same time, it can provide some scientific basis and valuable reference for colleges and universities to formulate relevant decision-making, and then provide the basis for the establishment of professional and orderly development of colleges and universities.

\section{A. The Harbin area university related to the Top-10 areas}

There are 27 colleges and universities in Heilongjiang, among them 16 in Harbin. The Harbin area universities related to the Top-10 areas are 14 , among which 12 are application undergraduate, as shown in Table 1.

The 16 colleges in table 2 mainly contain three cases:

- Research Talents Training 
Although the talents training of the two colleges in the table (No.1 and No.1) are closely related with the top ten areas, the Harbin Institute of Technology mainly cultivate aerospace research talents, and the Harbin Engineering University mainly cultivate three sea a nuclear research talents.

TABLE I. The HARBIN AREA UNIVERSITIES RELATED TO THE TOP-10 AREAS

\begin{tabular}{|c|c|c|c|}
\hline No. & School Name & $\begin{array}{c}\text { Top ten } \\
\text { focus areas }\end{array}$ & $\begin{array}{c}\text { Applicable } \\
\text { talent }\end{array}$ \\
\hline 1 & Harbin Institute of Technology & Yes & No \\
\hline 2 & Harbin Engineering University & Yes & No \\
\hline 3 & Northeast Forestry University & Yes & Partly \\
\hline 4 & Northeast Agricultural University & Yes & Partly \\
\hline 5 & Heilongjiang University & Yes & Partly \\
\hline 6 & $\begin{array}{c}\text { Harbin University of Science And } \\
\text { Technology }\end{array}$ & Yes & Partly \\
\hline 7 & Harbin Medical University & Yes & Partly \\
\hline 8 & $\begin{array}{l}\text { Heilongjiang University of } \\
\text { Chinese Medicine }\end{array}$ & Yes & Partly \\
\hline 9 & Harbin Normal University & Yes & Partly \\
\hline 10 & Harbin University of Commerce & Yes & Partly \\
\hline 11 & $\begin{array}{c}\text { Heilongjiang University of Science } \\
\text { and Technology }\end{array}$ & Yes & Yes \\
\hline 12 & Heilongjiang Engineering College & Yes & Yes \\
\hline 13 & Harbin University & Yes & Yes \\
\hline 14 & Harbin Institute of Finance & Yes & Yes \\
\hline 15 & Harbin Conservatory of Music & - & - \\
\hline 16 & Harbin sport university & - & - \\
\hline
\end{tabular}

\section{- Research-oriented talents and applied talents}

The 8 institutions in the table (serial number 3-10) have opened the major areas related to the ten major areas, including individual professional deep background, examples of strong, can cultivate research talents, such as Harbin University of Science and Technology Mechanical Engineering, Electrical Engineering and other engineering majors, the students contain both research and application talents. The Harbin University of Commerce should be emphasized in particular, except the economic management; the individual engineering professional strength is also strong, such as Energy and Power engineering, Packaging Engineering. At the same time, Harbin Normal University and Heilongjiang University not only cultivate normal and liberal arts talents, but also cultivate a large number of applied undergraduate talents in information class (0807) and computer class (0809).

\section{- Cultivation of Applied Talents}

Another 4 colleges and universities (No.11 to No.14) mainly have all the applied talents, such as Heilongjiang University of Science and Technology, Heilongiiang Institute of Engineering, they are purely science and engineering institutions, in addition to a small number of liberal arts professional, cultivate a large number of applied undergraduate talent, which are the important city base of applied undergraduate talent; Harbin university, as a municipal school in Harbin, these years are changing the concept of running schools, and gradually increase the application professional and the number of cultivated application-oriented undergraduate talents; Harbin Institute of Finance is a liberal arts-based institutions, which have also trained a number of application-

based computer talent(0809). (Note: 10 three-hospital colleges in Harbin are not in the scope of investigation)

TABLE II. THE TOP 10 AREAS RELATED COLLEGE PROFESSIONAL IN HARBIN

\begin{tabular}{|c|c|c|c|}
\hline No. & Top 10 areas & $\begin{array}{l}\text { relative college } \\
\text { professional }\end{array}$ & relative college \\
\hline 1 & $\begin{array}{l}\text { A new } \\
\text { generation of } \\
\text { information } \\
\text { technology }\end{array}$ & $\begin{array}{l}\text { Electronic information } \\
(0807), \text { computer } \\
(0809), \text { automation } \\
(0808) \text { and the } \\
\text { corresponding ad hoc, } \\
\text { etc. }\end{array}$ & $\begin{array}{c}\text { All the applied colleges in } \\
\text { Harbin }\end{array}$ \\
\hline 2 & $\begin{array}{l}\text { High-end } \\
\text { CNC } \\
\text { machine tools } \\
\text { and robots }\end{array}$ & $\begin{array}{l}\text { Mechanical engineering } \\
(0802) \text { and ad hoc } \\
\text { professional, robotics } \\
\text { and so on }\end{array}$ & $\begin{array}{l}\text { Harbin University of } \\
\text { Science And Technology, } \\
\text { Heilongjiang University of } \\
\text { Science and Technology, } \\
\text { Heilongjiang Engineering } \\
\text { College, Heilongjiang } \\
\text { University, Northeast } \\
\text { Forestry University, } \\
\text { Northeast Agricultural } \\
\text { University }\end{array}$ \\
\hline 3 & $\begin{array}{l}\text { Aerospace } \\
\text { equipment }\end{array}$ & $\begin{array}{l}\text { Aerospace }(0820) \text {, } \\
\text { energy and power and } \\
\text { the corresponding two } \\
\text { ad hoc professional }\end{array}$ & $\begin{array}{l}\text { Harbin University of } \\
\text { Science And Technology, } \\
\text { Harbin University of } \\
\text { Commerce, Heilongjiang } \\
\text { Engineering College }\end{array}$ \\
\hline & Marine & Transportation (0818), & \\
\hline
\end{tabular}

marine engineering equipment (0819) and the and high - corresponding ad hoc tech ships professional

\section{Advanced Mechanical}

Engineering (0802)

5 transportation

Automated (0808)

equipment

Transportation (0818)

Ad hoc Specialty

\section{Energy}

saving and new energy vehicles

\section{Vehicle engineering energy and power engineering}

$7 \begin{gathered}\text { Power } \\ \text { equipment }\end{gathered}$

Electrical engineering and automation, and so on

\section{Agricultural} equipment

Agricultural engineering (0823) and so on

Materials (0804) and

new material the corresponding ad hoc professional

Biomedical and high

10 performance medical equipment
Chemical and pharmaceutical (0813), pharmaceutical (1007), Chinese medicine (1008) and so on
Harbin University of Science And Technology, Heilongjiang University of Science and Technology, Heilongjiang Engineering College, Northeast Forestry University

Harbin University of Science And Technology, Heilongjiang University of Science and Technology, Heilongjiang Engineering College, Northeast Forestry University

Harbin University of

Science And Technology,

Heilongjiang University of

Science and Technology,

Heilongjiang Engineering

College, Heilongjiang

University, Northeast

Forestry University,

Northeast Agricultural University

Northeast Forestry

University, Northeast

Agricultural University

Harbin University of

Science And Technology,

Heilongjiang University of

Science and Technology,

Heilongjiang Engineering

College, Northeast Forestry University

Harbin Medical University, Heilongjiang University of Chinese Medicine, Harbin University of Commerce 
B. The number of applied undergraduates in colleges related to the top 10 areas

It can be seen from Fig. 2 that the number of people related to manufacturing in the 6900 to 7,500 people, combined with reference [3] projections can be seen that there are gaps in talent, but not very large, basically meet the requirements.

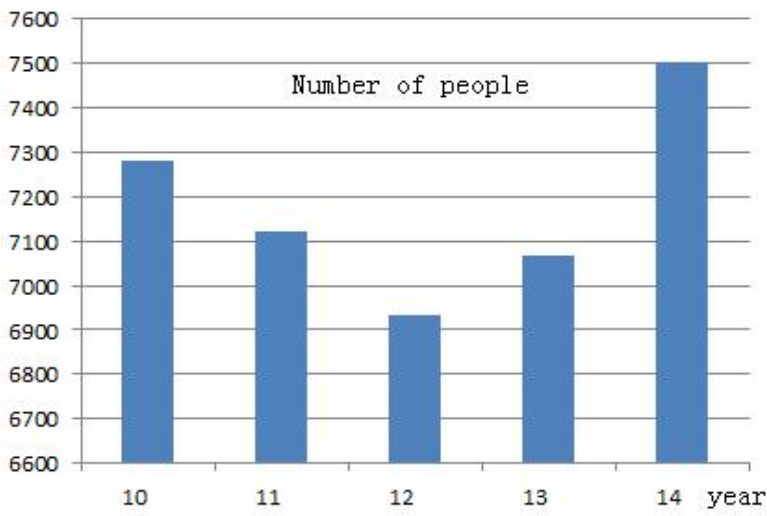

Fig. 2. The number of graduates corresponds to the top 10 areas in Harbin from 2010 to 2014

The data are derived from the Harbin Statistical Yearbook and references [3].

IV. ENGINEERING APPLIED TALENTS CULTIVATION DIMENSIONAL ANALYSIS -- A CASE STUDY OF TEN KEY AREAS UNIVERSITIES

- The universities have relatively perfect culture system, strong training ability, and can basically meet all kinds of talent needs. From the above data we can see that the macro in the region in the "application-based undergraduate talent training" on the number of colleges and universities, the number of relevant professional and personnel training scale, can meet the "China-made 2025" 17 refinement areas talent needs. Therefore, for our realization of the region "Chinamade 2025" provides a solid foundation for the region to provide a strong guarantee of talent pool.

- The number of "application-based undergraduate talent" supply and demand contradiction is prominent. This contradiction is mainly reflected in the micro, mainly in two aspects, on the one hand, the number of talent exceeds the demand, from the top 10 areas, the region to cultivate the "information technology talent" to cultivate a serious surplus, by the reference [3] we can see that the "information talent" surplus, and the region's information technology industry in the country is also in the weak industry, only some small and medium enterprises, scale enterprises are few, so "information technology talent" training surplus; the other is The number of talent in the embarrassing situation in short supply, for example, in the "energysaving and new energy vehicles," a serious lack of complex application talents. Especially in the "marine engineering equipment and high-tech ship", due to the special type of industry, in addition to Harbin Engineering University to provide scientific research personnel, there is no other universities in Harbin to provide relevant applied undergraduate talent.

- "application-based undergraduate talent" training, there are structural contradictions, teaching content is outdated, the teaching content cannot keep up with the needs of social development, less practical courses, teaching mode Single, the market talent and school training personnel do not correspond, resulting in graduates cannot find good jobs, companies cannot find the people they want. Strengthen the construction of outstanding teachers, the construction of "double teacher" team, set up in school teachers in turn to the enterprise training mechanism, to establish the appropriate assessment mechanism, so that make the teacher willing to go to business, willing to participate in enterprise-related production activities.

- According to the "application-oriented undergraduate talent", the university must change the thought, deepen the integration of production and education, to achieve "double main". To solve the above problems, the school must establish corporate personnel to participate in personnel training process of the new mechanism, but also for the establishment of enterprise personnel assessment mechanism to mobilize the enthusiasm of employees, so that business personnel to become a training personnel, collaborative education.

- Application-oriented undergraduate talent training should avoid "homogenization" personnel training, emphasizing "targeted". In the enterprise research process, we often hear the sentence that "all the school has the same training programs and curriculum settings". Although it is not accurate, but it plays the fact the cultivation of talent research, teaching and research type and teaching program convergence. It can be seen that in the process of "application-based undergraduate talents" and the cooperation between universities and enterprises, there must be enterprises involved in the process, so that different colleges and universities for specific industry graduates with the same professional ability to focus on to change the existing same training mode.

- Talent training in universities and "China-made 2025" are not docking. This situation is different from the above issues, mainly because of the Harbin does not correspond to the leading large enterprises, which led to some graduates outflow or diverted. For example, in the agricultural equipment, the Northeast Agricultural University agricultural mechanization of the annual graduates in the province there is no corresponding enterprises, only "Heilongjiang Agricultural Machinery Research Institute and Heilongjiang Academy of Agricultural Sciences Agricultural Engineering Research Institute" the two institutes demand is some researchers, which led to a large number of application-oriented talents flow into other provinces or diverted, according to the reference[3], we can know that China's agricultural machinery and equipment personnel annual gap of about 25,000 people. And 
there are a few such problems in the professional, such as "high-end CNC machine tools and robots" also exist in the absence of enterprises or not caused by the loss of talent situation.

\section{CONCLUSION}

"China-made 2025" is a major strategic plan in the national development trend at home and abroad, standing on the national strategic security point, the core is to promote the development of manufacturing innovation, to achieve quality and efficiency. And the northeast region is an important old industrial base in China, with a solid industrial base and a good and complete industrial structure, so "China-made 2025" must be in the northeast region to achieve the first problem. Harbin as an important city of the Northeast, is new China's industrial cradle, the relevant enterprises in Harbin to achieve "Chinamade 2025 " is the country to achieve "China-made 2025" an important guarantee, so the talent structure in this region, "the application of undergraduate talent," the number, structure and quality of research important. The subject will give some rationalization proposals of the corresponding issues for the relevant enterprises and institutions to develop a policy to provide a reasonable basis.

\section{ACKNOWLEDGMENT}

It is supported by the 13th Five-year Higher Education Scientific Research Project (16Q170, 16Q172), the Higher Education Computer Education Research Project (160010) and the Heilongjiang Province Educational Scientific Planning Project (GJC1316149).

\section{REFERENCES}

[1] China-made 2025 [Z].Beijing: People's Publishing House.2015.

[2] “China-made 2025” and Engineering and Technical Talent Training Group. “China-made 2025” and Engineering and Technical Talent Training [J]. 《Research on Higher Engineering Education,2015(6).

[3] China Education Science Research Institute. Research on Perfecting Talent Training System in Key Areas of Advanced Manufacturing Industry [J]. Educational Research, 2016(1).

[4] Harbin Municipal Government. Into the city of Harbin. http://www.harbin.gov.cn/zjhrb/cszj/tjnj.htm

[5] YU Zhijing, LIU Hai, YUE Jinfeng. Made in China 2025 and technical skills training [J]. Vocational and technical education,2015.21(36) 